IRA-International Journal of Education \& Multidisciplinary Studies

ISSN 2455-2526; Vol.07, Issue 03 (2017)

Pg. no. 240-249

Institute of Research Advances

http://research-advances.org/index.php/IJEMS

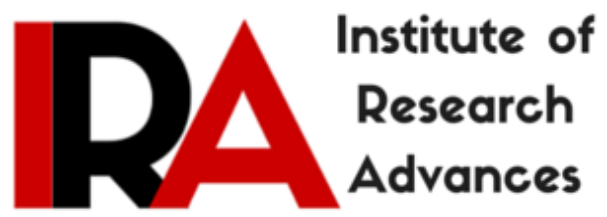

\title{
Construction and Validation of Environmental Ethics Attitude Scale
}

\author{
Nikhat $^{1}$ \& Zebun Nisa Khan ${ }^{2}$ \\ ${ }^{1,2}$ Department of Education, Aligarh Muslim University, \\ Aligarh, 202002, India.
}

Type of Review: Peer Reviewed.

DOI: http://dx.doi.org/10.21013/jems.v7.n3.p9

\section{How to cite this paper:}

Nikhat, Khan, Z. (2017). Construction and Validation of Environmental Ethics Attitude Scale. IRA International Journal of Education and Multidisciplinary Studies (ISSN 2455-2526), 7(3), 240-249. doi:http://dx.doi.org/10.21013/jems.v7.n3.p9

(C) Institute of Research Advances

\section{(cc) EY-NO}

This work is licensed under a Creative Commons Attribution-Non Commercial 4.0 International License subject to proper citation to the publication source of the work.

Disclaimer: The scholarly papers as reviewed and published by the Institute of Research Advances (IRA) are the views and opinions of their respective authors and are not the views or opinions of the IRA. The IRA disclaims of any harm or loss caused due to the published content to any party. 


\section{ABSTRACT}

The aim of the study is to assess the attitude of teachers towards environmental ethics and to develop ethics in them in case of lack of concern towards it. After reviewing so many relevant literatures the investigators considered the three dimensions of environmental ethics i.e., anthropocentrism, ecocentrism and bio-centrism and constructed 84 items based on these dimensions. Investigators consulted 15 experts from various educational and environmental fields for the content and face validity of scale. After expert judgment, 19 items were rejected for overall ambiguities while 65 items were selected for preliminary try-out of the scale over 100 teachers selected through Simple Random sampling technique. Final draft of the scale with 54 items was administered over 300 teachers both from eastern and western Uttar Pradesh. After final item analysis of Environmental Ethics Attitude Scale, 46 items were retained on the basis of the t-value, which was found significant (0.05 level of significance). Out of these 46 items, 34 are positive and 12 are negative statements. The reliability of the tool was 0.836 by Alpha Cronbach to check internal consistency of the tool and by Split Half Test was 0.734 .

Keywords: Attitude, Environmental ethics, Anthropocentrism, Eco-centrism, Bio-centrism.

\section{Introduction}

God has created all the creatures and resources at the disposal of mankind and give us the honor of the supreme creatures of God. The holy books repeatedly reveal the judicious use of God gift less on self more on welfare of the others. The satanic force influences the human being so much so that leads to increasing greedy excessive demand. Basically, in the early stage man was a biotic component in the biosphere and lived harmoniously with other components of biosphere. The increased intellectual knowledge forced him to do all the non-harmonious method of science and technology to exploit the natural resources without considering the ill effects leading to ecological crisis and change the biosphere into controller of biosphere. The main environmental issues today are wide-ranging and all encompassing: deforestation, biodiversity, soil erosion, industrial and municipal pollution, pesticide build up and climatic change. These issues are being further compounded with population explosion, food crisis, hunger, malnutrition, poverty, insanitation that will lead to extinction of all living being including human being also (Dash, 2010). Rapid population growth is also antagonized as it is deemed to be a threat to nature (Telles, J.P.R., 2015).These have been caused by anthropogenic interventions in the natural and selfsustaining cycles. The human ambition for a higher living standard has hammered consumerism, ignoring the lasting and adverse impact of this hammer on earth's limited resources. Education has always been a process by which people fitted to live successfully in their environment. Only right type education can develop systematic, organized and awakened social mind (Anand, 2002). These adjustments have been a matter of physical skills acquits discovery how to maintain a healthy life by using resources at disposal learning of behavior from elder members of the society. At that stage all education were environmental. However the present history of human being has been marked by technological and social changes that simultaneously inverted the exploitation of natural resources reshaping them in ways to suit their ambition in an attempt to improve the quality of living. At the same time one must know that what today's world craves for is an environmental worth living. To make the environment worth living, it needs a drastic change in our philosophy of life, in our habits, outlook, attitude, and values. Only education, undoubtedly, has the resources to achieve this goal.

\section{Review of related literature}

Environment deals with pattern of behavior that should follow while interacting with environment. The effective route to achieve the goal of environmental oriented education is through the inclusion of ethics education as a significant aspect of any environmental education programme (Rai and Sharma, 2011). But anthropocentric individuals are less likely to act to support the environment because such support may often threaten other human centered values (e.g. quality of life, accumulation of wealth). Thompson and 
Barton (1994) claimed that eco-centric individuals are more likely to act to support the environment even if such action involves discomfort, inconvenience and expense. All plants and living things have the right to subsistence and inherent value of their own, and should be given equal respect (Taneja,N and Gupta,K., 2015).According to Yang (2006), anthropocentrism, eco-centrism and bio-centrism all provide unique and some reasonable ethical justification for environmental protection.

\section{Framework of the study}

Our environment (physical and social) is degrading because of the number of problems, which are mostly man-made like pollution and population explosion, contamination of water etc. Man is actually befooling himself and not his environment, because environment itself never changes on its own. Need of the hour is to have environmentally conscious citizens, who are concerned for saving the environment from disasters. It might happen only when people are knowledgeable about their environment and associated problems; and are aware of the solutions to these problems and motivated to work for that. This naturally means change in the attitude and behavior of the individual. Teaching of Environmental Ethics is an important method to raise the concept of think globally and act locally which students need to learn to understand nature of environment and environmental literacy (Wongchantra and Nuangchalerm, 2011). The aim of constructing Environmental Ethics Attitude Scale is to promote particular values with respect to the environment and for those who do not clearly advocate for a set of values, although they may inform value reasoning about the environment.

\section{Definition of key terms}

\section{Environmental ethics}

Environmental ethics can be understood in terms of an expanding range of moral standing.

Environmental issues like nuclear waste disposal, the growth of human population and resource depletion came to the fore; it was discussed and argued by many ethicists that moral standing be extended for the future generations of human being.

\section{Anthropocentrism}

Anthropocentrism thinks that entities like animals, plants, mineral resources etc are resources that may be exploited justifiably for the benefit of humankind, which is regarded as different and superior to nature.

\section{Eco-centrism}

Eco-centrism to distinguish it from bio-centrism holds that ecological collections such as eco-systems, habitats, species, and populations are the central objects for environmental concern (Encyclopedia Britannica).

\section{Biocentrism}

All life deserves equal moral consideration or has equal moral standing is the ethical perspective of Biocentrism. Although elements of biocentrism can be found in several religious traditions, it was not until the late decades of the 20th century that philosophical ethics in the Western tradition addressed the topic in a systematic manner (Encyclopedia Britannica).

\section{Attitude}

An attitude is a relatively enduring organization of beliefs, feelings, and behavioral tendencies towards socially significant objects, groups, events or symbols. 


\section{Methodology}

The present study has been conducted for the construction and validation of the Environmental Ethics Attitude Scale, which has a significant and immense value in the field of education. Attitude is considered as a learned disposition to respond positively or negatively to certain objects, situations, institutions, concepts or persons (Aiken, 2002).

\section{Construction and standardization of the Environmental Ethics Scale}

Following are the steps of construction and standardization of scale:

\section{Planning and writing of the statements}

For the construction of Environmental Ethics Scale the investigators goes through so many previous studies, theoretical background of the environmental ethics and previous related tools. After reviewing so many related literatures it was found that the environmental ethics dimensions could be assessed through the different perspective, either through the philosophical point of view, sociological point of view or biological point of view. The investigator chooses a midway between sociological and biological point of view as these perspectives has long-term impact on individual teachers attitude towards environmental ethics concern. The investigators constructed every item that should be associated with the dimensions prescribed for the environmental ethics. The investigators generated as many as statement as possible in order to cover all the dimensions of the environmental ethics. In this way 84 statements were prepared from three dimensions of environmental ethics.

\section{Expert consultation}

Investigators consulted and discussed with fifteen experts from different educational fields for the face validity of the first draft of the environmental ethics. After the suggestion given by the experts the investigators removed 19 items which has ambiguity and the final draft was prepared with 65 items. The investigators constructed a table, which shows that the items were distributed under each dimension.

\section{Preliminary try-out of the test}

The preliminary draft having 65 items with 5 alternatives administrated over 100 teachers through Random Sampling Method. Using Likert Five Point Scale, their responses were scored (1=strongly disagree, $2=$ disagree, $3=$ neutral,4=agree and 5=strongly agree).The investigators rejected 11 items, which were not understood by the students. After preliminary try out of the test 54 items were selected for the final tryout of the scale.

\section{Final tryout of the scale}

The final drafts of scale with 54 items were administered over the teachers of both Eastern and Western U.P. state of India. The sample size for the final try-out of the scale constituted 300 teachers both inservice and pre-service selected through the Simple Random Sampling Technique. The time given for the filling of the scale was 30 minutes.

\section{Item analysis of the scale}

After the final try-out, the test was scored and arranged in descending order. The upper $25 \%$ and lower $25 \%$ of the protocol was considered by the investigators to find out the t-value of the each item. On the basis of the t-value, 46 items were found significant while 8 items were not significant at 0.05 , level of significance. Out of these 46 items, 34 are positive worded items while 12 are negative worded. 


\section{Psychometric Procedure}

After try out and final item analysis of scale the investigators tested the reliability and validity of the scale.

\section{Reliability of the scale}

The reliability of the Environmental Ethics Attitude Scale was computed by Spilt Half (odd-even) method and found to be 0.734 . To check the internal consistency of the items Alpha Cronbach Reliability was also computed and found to be 0.836 , which is very high.

\section{Validation of the scale}

Validity may be refers to the extent to which an instrument measures what it is designed to measure (Singh, 1998).In order to determine the validity of the scale the investigators determined the face-validity, content validity and construct validity of the scale. For the face validity the investigators contacted 15 experts from different educational fields and rejected those items, which have ambiguity. In the case of content validity the investigators confirmed that the content was taken from authentic sources and the statements covered all the dimensions of the environmental ethics. For the confirmation of this the investigators also consulted with the environmental studies experts. In order to check the construct validity of the scale the investigators used Pearson's Correlation Coefficient Method in which score of each item is correlated with the total score of the scale. All the items correlation coefficient was ranging from 0.542- 0.892 except the 8 items whose correlation coefficient was found to be below 0.256 .

Table 1: Showing the reliability and the validity of the scale

\begin{tabular}{|l|l|l|}
\hline Reliability of the scale & Spilt half method 0.734 & $\begin{array}{l}\text { Alpha Cronbach method(internal } \\
\text { consistency) } 0.836\end{array}$ \\
\hline Validity of the scale & Face validity, content validity and construct validity \\
\hline
\end{tabular}

\section{Conclusion}

The Environmental Ethics Attitude Scale have a great extent of reliability and validity when examined in relation to a representative sample of Teachers aged between 21- 55 conducted over the Eastern and Western U.P. State of India. The most important inference of the questions of Environmental Ethics Attitude Scale is that it can be answered by anyone due to simply worded statements. The aim for constructing this tool is to develop critical thinking skills among teachers, which allow them to examine ethical issues surrounding the environment. No programme of education can be implemented without the willing and cooperation of teachers (Singh and Singh, 2013).NCTE discussion document (2004) also gives importance to environmental ethics education for pre-service teachers and in-service teachers and its inclusion in the teacher-training program. It is necessary to create critical thinking opportunities in the classroom with necessary components and then discuss special considerations for teaching critical thinking in the context of natural resource and environmental ethics education. 


\section{References}

1. Aiken, R. L. (2002). Psychological Testing and Assessment (11 ${ }^{\text {th }}$ ed.). Boston: Allyn\& Bacon.ISBN-10: 0205354718.

2. Anand, A. (2002). A Study of Relationship between Environmental Awareness and Scientific Attitudes among Higher Secondary Students of Varanasi City. Unpublished Ph.D. Thesis. Faculty of education, B.H.U., Varanasi, India.

3. Desh, B. et.al. (2010). Education for Sustainable Development. Indian Educational Review, 47, 727. ISSN: 0019 - 4700. ISSN 0972-561X.

4. https://www.britannica.com/topic/ecocentrism

5. https://www.britannica.com/topic/anthropocentrism

6. https://www.britannica.com/topic/biocentrism

7. Hogg, M. \& Vaughan, G. (2005). Social Psychology (4th edition). London: Prentice-Hall.ISBN10: 0273686992.

8. Jha, P.K. (1998). Manual for Environmental Awareness Ability Measure. Agra, India: National Psychological Corporation.

9. NCTE (2004). Some Specific Issues and Concern of Teacher Education, A Document, NCTE New Delhi.

10. Rai, A.K.and Sharma,R.N. (2011). Environmental Ethics Education: A Necessity to Initiate Environmental Oriented Action, SPIJE, 1(1), 33-37.ISSN: 2231 - 2323.

11. Singh, A. \& Singh, S. K. (2013).Opinion of Teachers Educators Regarding Environmental Education and Environmental Ethics. Shaikshik Parisamvad (An International Journal of Education) SPIJE, 3(1). ISSN $2231-2323$.

12. Singh, A.K. (2002). Tests, Measurements and Research Methods in Behavioral Sciences. Bharati Bhawan, Patna, India.ISBN-10: 8177097431.

13. Taneja, N. and Gupta, K. (2005). Environmental Ethics and Education - A Necessity to Inculcate Environmental Oriented Cognizance. International Advanced Research Journal in Science, Engineering and Technology, 2(1).ISSN 2393-8021

14. Telles, J. P. R. (2015).Televised Ecotopianism: An Eco-critical Analysis on Environmental Risk and Risk Reduction Discourses in Philippine Environmental Documentaries. SEARCH: The Journal of the South East Asia Research Centre for Communications and Humanities. 7(2), 3559.ISSN 2229-872X.

15. Thompson, S.C.G. \& Barton, M.A. (1994). Eco-centric and Anthropocentric Attitudes toward the Environment. Journal of Environmental Psychology, 14,149-157. ISSN: 0272 - 4944.

16. Wongchantra, P. and Nuangchalerm, P. (2011). Effects of Environmental Ethics and Infusion Instruction on Knowledge and Ethics of Undergraduate Students. Research Journal of Environmental Sciences, 5(1), 77-81. ISSN 1819-3412

17. Yang, T. (2006).Towards an Egalitarian Global Environmental Ethics. Environmental ethics and international Policy, UNESCO. ISBN: 978-92-3-104039-9. 


\section{APPENDIX}

\section{Manual of Environmental Ethics Attitude Scale ( Nikhat \& Zebun)}

Please fill in the following information:

1. Name:

2. Gender:

Male ( ) Female ( )

3. Academic qualification: Pre-University ( ) Graduate ( ) Post-graduate ( )

4. Area of specification: Arts ( ) Science ( ) Commerce ( )

5. Present residence: Town ( ) Village ( )

6. Religion: Hindu ( ) Muslim ( )

Sikh ( ) Christian ( )

7. Monthly Income:
a] 50,000 and above ( )
b] 30,000 to 49,000 ( )
c] 20,000 to 29,000 ( )

d] 10,000 to 19,000 ( )

e] Below 10,000 ( )

8. Father's Educational Qualification:

$10^{\text {th }}() 12^{\text {th }}$ ( ) Graduate ( ) Post-graduate ( ) Above Post-graduate ( )

9. Mother's Educational Qualification:

$10^{\text {th }}\left(\right.$ ) $\quad 12^{\text {th }}($ ) Graduate ( ) Post-graduate ( ) Above Post-graduate ( )

Directions: This scale is meant for assessing the attitude of respondents towards various aspects of environmental ethics. There is no right or wrong answer to any statement. What is required is your personal feeling/ opinion about the idea given in each statement. For each statement, five alternatives are given and you have to express your opinion by selecting any one of the five alternatives and making tick mark $(\sqrt{ })$ in the cell given below the preferred response here:

SA means Strongly Agree

A means Agree

UD means Undecided

D means Disagree

SD means Strongly Disagree

The variable or trait measured (environmental ethics scale) has 3 dimensions:-

1. Anthropocentrism

2. Biocentrism

3. Ecocentrism 
Example: we should not kill animals and birds for pleasure purpose.

\begin{tabular}{|l|l|l|l|l|}
\hline SA & A & UD & D & SD \\
\hline
\end{tabular}

Environmental Ethics Attitude scale ( Nikhat and Zebun)

\begin{tabular}{|c|c|c|c|c|c|c|c|}
\hline S.No & Statements & S.A & $\mathrm{A}$ & UN & $\mathrm{D}$ & SD & Score \\
\hline 1. & $\begin{array}{l}\text { A preservative used in packaged food is not } \\
\text { good for health }\end{array}$ & $\square$ & $\square$ & $\square$ & $\square$ & $\square$ & \\
\hline 2. & Bio pesticides protect the environment. & $\square$ & $\square$ & $\square$ & $\square$ & $\square$ & \\
\hline 3. & $\begin{array}{l}\text { Injudicious use of chemical fertilizers } \\
\text { erodes the soil }\end{array}$ & $\square$ & $\square$ & $\square$ & $\square$ & $\square$ & \\
\hline 4. & $\begin{array}{l}\text { Non-vegetarian food habits need not to be } \\
\text { changed. }\end{array}$ & $\square$ & $\square$ & $\square$ & $\square$ & $\square$ & \\
\hline 5. & $\begin{array}{l}\text { We can honor the animals by providing } \\
\text { proper food, shelter and protection from } \\
\text { pests. }\end{array}$ & $\square$ & $\square$ & $\square$ & $\square$ & $\square$ & \\
\hline 6. & $\begin{array}{l}\text { Killing of animals for food by the tribal } \\
\text { should be allowed. }\end{array}$ & $\square$ & $\square$ & $\square$ & $\square$ & $\square$ & \\
\hline 7. & $\begin{array}{l}\text { Conversion of forestland into agricultural } \\
\text { and industrial land is always risky. }\end{array}$ & $\square$ & $\square$ & $\square$ & $\square$ & $\square$ & \\
\hline 8. & $\begin{array}{l}\text { Increase in government revenue by } \\
\text { reduction in forest area has a long-term } \\
\text { adverse effect. }\end{array}$ & $\square$ & $\square$ & $\square$ & $\square$ & $\square$ & \\
\hline 9. & $\begin{array}{l}\text { Introduction of afforestation programme is } \\
\text { mere wastage of time and energy }\end{array}$ & $\square$ & $\square$ & $\square$ & $\square$ & $\square$ & \\
\hline 10. & $\begin{array}{l}\text { Acid rain is harmful for historical } \\
\text { monuments as well as for forests }\end{array}$ & $\square$ & $\square$ & $\square$ & $\square$ & $\square$ & \\
\hline 11. & $\begin{array}{l}\text { Proper use of chemical fertilizers is not } \\
\text { harmful for agriculture production }\end{array}$ & $\square$ & $\square$ & $\square$ & $\square$ & $\square$ & \\
\hline 12. & $\begin{array}{l}\text { We can use solar energy quite safely to } \\
\text { promote of environmental protection }\end{array}$ & $\square$ & $\square$ & $\square$ & $\square$ & $\square$ & \\
\hline 13. & $\begin{array}{l}\text { Producers of more greenhouse gases should } \\
\text { be punished without discrimination. }\end{array}$ & $\square$ & $\square$ & $\square$ & $\square$ & $\square$ & \\
\hline 14. & $\begin{array}{l}\text { More consumption of natural resources by } \\
\text { the rich people is unethical. }\end{array}$ & $\square$ & $\square$ & $\square$ & $\square$ & $\square$ & \\
\hline
\end{tabular}




\begin{tabular}{|c|c|c|c|c|c|c|}
\hline 15. & $\begin{array}{l}\text { Toxic wastes are always harmful to life } \\
\text { including human being. }\end{array}$ & $\square$ & $\square$ & $\square$ & $\square$ & $\square$ \\
\hline 16. & $\begin{array}{l}\text { Huge sum of money spent to control } \\
\text { environmental pollution could be used for } \\
\text { better future. }\end{array}$ & $\square$ & $\square$ & $\square$ & $\square$ & $\square$ \\
\hline 17. & $\begin{array}{l}\text { Nuclear wastes should be disposed of with } \\
\text { utmost care. }\end{array}$ & $\square$ & $\square$ & $\square$ & $\square$ & $\square$ \\
\hline 18. & $\begin{array}{l}\text { Non-biodegradable bags need not to be } \\
\text { banned. }\end{array}$ & $\square$ & $\square$ & $\square$ & $\square$ & $\square$ \\
\hline 19. & $\begin{array}{l}\text { Damping the solid waste may reduce } \\
\text { lowland water filled area. }\end{array}$ & $\square$ & $\square$ & $\square$ & $\square$ & $\square$ \\
\hline 20 & $\begin{array}{l}\text { Atomic energy should be used only for } \\
\text { peaceful purposes by all countries. }\end{array}$ & $\square$ & $\square$ & $\square$ & $\square$ & $\square$ \\
\hline 21. & $\begin{array}{l}\text { Picnic litter left by people should be heavily } \\
\text { fined. }\end{array}$ & $\square$ & $\square$ & $\square$ & $\square$ & $\square$ \\
\hline 22. & $\begin{array}{l}\text { More and more windmills should be } \\
\text { installed in the coastal region for energy } \\
\text { production. }\end{array}$ & $\square$ & $\square$ & $\square$ & $\square$ & $\square$ \\
\hline 23. & $\begin{array}{l}\text { Protection of environment is only a } \\
\text { responsibility of government. }\end{array}$ & $\square$ & $\square$ & $\square$ & $\square$ & $\square$ \\
\hline 24. & $\begin{array}{l}\text { Loss of energy at every level should be } \\
\text { checked for future use. }\end{array}$ & $\square$ & $\square$ & $\square$ & $\square$ & $\square$ \\
\hline 25 & $\begin{array}{l}\text { Most of the people directly or indirectly } \\
\text { responsible for ozone layer depletion. }\end{array}$ & $\square$ & $\square$ & $\square$ & $\square$ & $\square$ \\
\hline 26. & $\begin{array}{l}\text { People who are indifferent towards } \\
\text { environmental protection should be } \\
\text { punished. }\end{array}$ & $\square$ & $\square$ & $\square$ & $\square$ & $\square$ \\
\hline 27. & $\begin{array}{l}\text { The interest of future generation should not } \\
\text { be sacrificed for luxurious life. }\end{array}$ & $\square$ & $\square$ & $\square$ & $\square$ & $\square$ \\
\hline 28. & $\begin{array}{l}\text { Dumping of waste product should be at a } \\
\text { reasonable distance from residential areas. }\end{array}$ & $\square$ & $\square$ & $\square$ & $\square$ & $\square$ \\
\hline 29. & $\begin{array}{l}\text { Smoking at public place should not be a } \\
\text { matter of concern. }\end{array}$ & $\square$ & $\square$ & $\square$ & $\square$ & $\square$ \\
\hline 30. & $\begin{array}{l}\text { Urination at improper place should be } \\
\text { punished heavily. }\end{array}$ & $\square$ & $\square$ & $\square$ & $\square$ & $\square$ \\
\hline 31. & $\begin{array}{l}\text { If energy is free of cost it can be used in } \\
\text { excess. }\end{array}$ & $\square$ & $\square$ & $\square$ & $\square$ & $\square$ \\
\hline
\end{tabular}




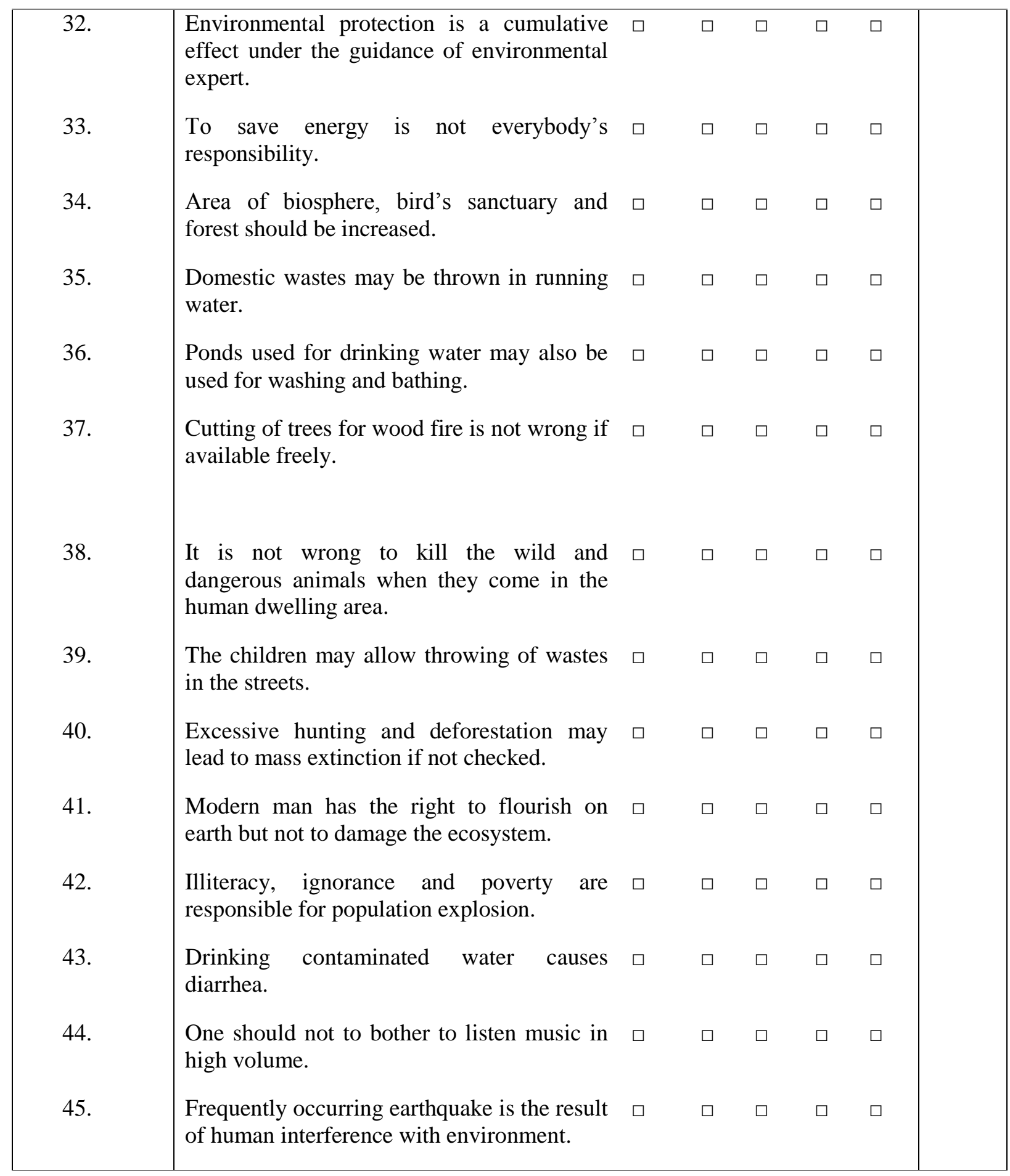

